International Journal of Engineering \& Technology, $7(3.24)(2018) 1-7$
International Journal of Engineering \& Technology
Website $:$ www.sciencepubco.com/index.php/IJET
Research paper

\title{
Analysis of the Potential Hazard Identification and Risk Assessment (HIRA) and Hazard Operability Study (HAZOP): Case Study
}

\author{
Bambang Suhardi ${ }^{1}$, Pringgo Widyo Laksono ${ }^{2}$, Andhika Ayu V.E ${ }^{3}$, Jafri Mohd.Rohani $^{4}$, Tan Shy Ching ${ }^{5}$ \\ ${ }^{1,2,3}$ Department of Industrial Engineering, Faculty of Engineering, Universitas Sebelas Maret, Surakarta, Central Java, Indonesia \\ ${ }^{4,5}$ Faculty of Mechanical Engneering, Universiti Teknologi Malaysia, 81310, Skudai, Johor, Malaysia \\ *Corresponding author E-mail:bambangsuhardi@staff.uns.ac.id
}

\begin{abstract}
This study aims to investigate the potential hazards and accidents that might occur at batik printing PT. Batik Merak Manis and recommends practical solutions to enhance safety and health at the workplace. This research adopts Hazard Identification Risk Assessment (HIRA) and Hazard and Operability Studies (HAZOP) to perform risk identification and assessment in the workplace. There are 17 findings of potential hazards in the production areas of batik printing which can be categorized into five types of hazards including: workers attitude, work posture, work procedure, workstation, and physical work environment. Of the risk assessment, the obtained value of $34 \%$ in the category of extreme hazard, $24 \%$ hazard in the high and medium category respectively, and 18\% lower hazard category. Proposed improvements are made based HAZOP analysis worksheet. The proposed practical solutions include improvements in work attitude, work posture, and physical work environment.
\end{abstract}

Keywords: HAZOP, HIRA, Risk Assessment, Source of Hazard.

\section{Introduction}

Hazard is the cause or circumstances that have the potential to cause injury or illness to humans, property damage, and pollutions of the environment or a combination of all of them [26]. The term of hazard shows as an incident that could cause injury [8]. Hazards are the potential causes that endanger human health, property or the environment, which may cause accidents under certain [23]. All work activities contain the potential danger or hazard [24]. Potential hazards in the process of making batik are caused by working in the unsafe conditions, such as working posture is not ergonomic, contacting with chemicals in the dyeing process, exposing to the heat coming from the furnace during the process coloration [1].

Agusti [2] stated that the space and work equipment used during the process of batik in the textile industry, in general, are still categorized as less ergonomic. This condition is due to the working facilities do not consider the needs and employability of workers. For instances, seating, gawangan and physical working environments such as poor lighting levels, high temperature and environmental conditions that are considered as less clean. Besides, the institution of Clean Batik Initiative Centre $[10,11,12,6]$ has highlightedthe use of chemicals in the batik industry. The used chemical in batik industries comprised of caustic soda $(\mathrm{NaOH})$, hydrochloric acid (HCL), sodium nitrite $\left(\mathrm{NaNO}_{2}\right)$, hydrogen peroxide $\left(\mathrm{H}_{2} \mathrm{O}_{2}\right)$, sodium dithionite $\left(\mathrm{Na}_{2} \mathrm{~S}_{2} \mathrm{O}_{4}\right)$, sodium carbonate $\left(\mathrm{Na}_{2} \mathrm{CO}_{3}\right)$, sodium silicate $\left(\mathrm{Na}_{2} \mathrm{SiO}_{3}\right)$ and naphtol dye. These chemical materials are categorized into hazard and toxic substances. A correct working procedure is necessary to be considered in handling those chemical materials [31]. Such hazardous and toxic materials in case of direct contact with the skin can cause a burnng sensation on the skin, itching and if there's a direct contact in the long term will lead to disease and chronic effects.

Labour is one of the most important assets in the batik industry. Emploers must provide assurance of safety and health for workers. The Occupational Safety and Health department is attempted to ensure the integrity and physical and spiritual perfection of man and employment in particular together with the results of his work in order towards a just society, and prosperous [33, 9]. Work safety is a process to plan and control the situation of the potential workplace accidents through the preparation of standard. Claimed that the awareness of employers to provide an assurance of safety and health for workers in Indonesia is still at the low level [5, 25].

An enterprise can be classified as a small or medium enterprise (SME) if it has a number employee from 5 to 99 people [29]. PT. Batik Merak Manis which is categorized as SME is one of the batik's producer in Solo. Production of batik printing in this company is based on the Indonesian National Standard (SNI) of batik. This company produces some products such as batik printing (machine printed batik), batik tulis (written batik), and batik cap (manually printed batik) [7]. Batik printing is more contributing to economic growth of the textile industry compared to batik tulis and batik cap. The production of machine printed batik fabric reached 4.000 pieces per day. The production quantities of batik cap and batik tulis, each for 800 pieces and 20 pieces per day. This study focused on batik printing workstation as its high production amount per day compared to the other products. The production process of batik cloth printing as shown in Figure 1: a) preparation of raw materials such as mori cloth, b) grounding (the basic of dyeing process), c) preparation of printing, d) printing (printing 
process of batik patterns on cloth), e) drying, f) steaming (fumigation process that aims to lock in color so that the color becomes more assertive and not easily fade), g) washing and drying, h) calendering (process for polishing cloth using a machine calendar so that the fabric becomes shiny).

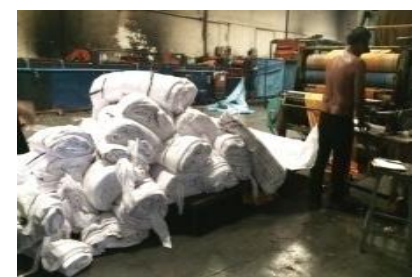

a. Material preparation

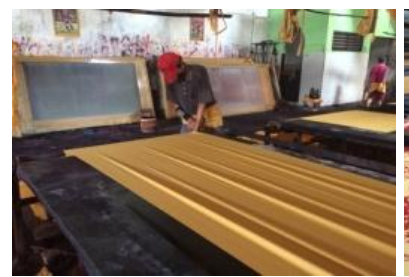

c. Printing preparation

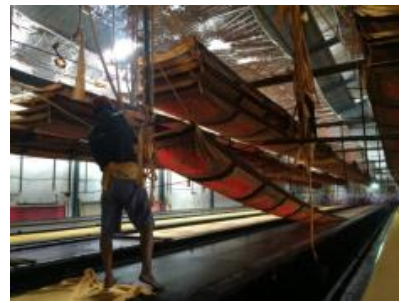

e. Drying

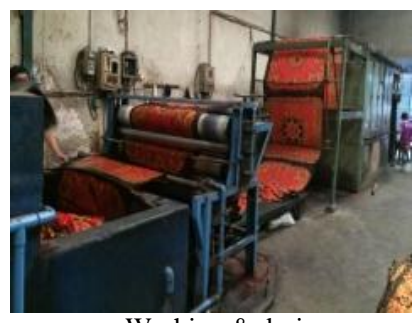

g. Washing \& drying

Figure 1 Production proce

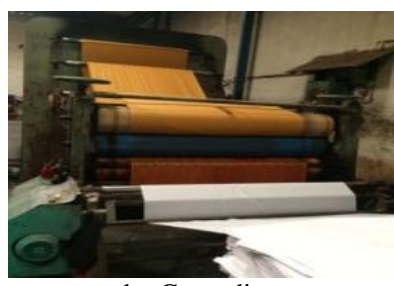

b. Grounding

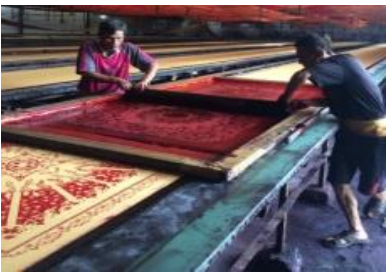

d. Printing process

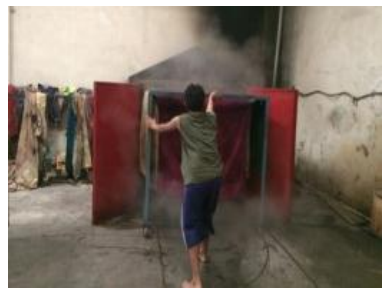

f. Steaming

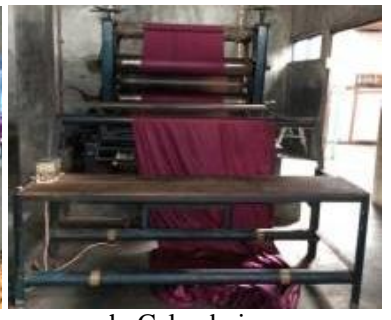

h. Calendering
Based on the observation of the production process in batik printing workstation, it has tendency to ignore the aspects of safety and health at work. Employees work in an environmental condition that is not clean and orderly such that tools and raw materials for production are not kept and stored appropriately. The working room is poor in air circulating or ventilation system. The chemicals used in coloring are not labeled correctly. The employees need to memorize the shapes and colors of the apparatus in using the desired chemicals. Furthermore, most of the employees do not use personal protective equipment (PPE), particularly gloves and masks. These conditions resulted in a high potential risks to affect the safety and health of the employees in batik printing workstation.

Although the application of HIRA and HAZOP in industry has been discussed by many authors [ 18, 19, 20, 9] only a few attempts have been made to integrate HIRA and HAZOP. Based on our best of knowledge, there is less specific attention paid on investigating the potential hazards using systematic hazard or risks assessment approach, particularly for SME industry.

The aim of this study is to investigate the potential hazards and accidents that might occur at batik printing workstation and provides improvement solutions for prevention of occupational accidents. This research adopts and integrates methods HIRA and
HAZOP to perform potential risks assessment systematically. HIRA method is a technique used for identifying potential hazards of workplace accidents. Whilst, HAZOP is a method used to review a process or a system operating on a systematic basis in order to determine whether irregularities process can lead to incidents or accidents unwanted

HIRA method is a screening process in a structured and systematic process to identify and evaluate the operation of the problem in order to reduce accidents $[15,6]$. The HIRA method has been used by $[18,20]$ to identify and control hazards in workstation. Risk analysis requires knowledge of probability (frequency and possibilities), and its consequences (impacts, damage, or injury level) from a process of events. Risk assessment is the process used to determine how to manage the risks that have been identified based on the analysis [21]. According to [15], the best way to reduce the danger is to get rid of everything that has the potential hazards that lead to accidents. HIRA identification process used by [4] as follows: 1) hazard identification; 2) risk assessment; 3) risk control.

HAZOP is a systematic safety study towards the assessment of safety and the operation of complex equipment or production process [19]. Interest of HAZOP is used to identify possible hazards that arise in facilities management in the company, eliminate a major source of accidents, such as toxic releases, explosions and fires [14]. Several studies have been used the HAZOP method in the industry to assess the safety operations in workplace $[19,27]$.

\section{Methodology}

HIRA and HAZOP are applied to analyze the potential hazard in present SME batik printing. The data collection is performed using three ways: i) observation, ii) interviews, and iii) measurement. Direct observation is made to observe the activities of the production process of batik printing. Interviews are conducted with employers to understand the standard operating procedures (SOP) of batik printing production process as well as to determine the discomfort felt by them. Measurements are made to determine the condition of the physical environment (temperature, humidity, and wind speed) and work posture.

Application of HIRA and HAZOP methods in this study are divided into three stages. The first stage involved the implementation of HIRA method with the following steps:

1. Understand the sequence of the production process of batik printing (GEMBA).

2. Identify the hazards in the area of making batik printing based on observations, interviews, and measurement. Hazard identification includes location, photos of activities, description of the findings of hazards, risk and source of hazard from the beginning until the end of the process to understand all the deviations that occur.

3. Conduct a risk assessment of the hazards that have been identified to determine the severity or hazard anything that has the greatest risk. Calculations to assess the level of risk as follows:

Risk Level $=$ likelihood $\mathrm{x}$ consequence.

The guidelines to determine the criteria of likelihood and consequences and risk matrix can refer to work done by [4].

The second stage is to make HAZOP worksheet in the following order based on the findings made by HIRA:

1. Classify potential hazards found in the production process of batik printing.

2. Describe deviation or irregularities that occurred during the production process of batik printing.

3. Describe the cause (cause).

4. Describe that may result from these deviations (consequences).

5. Determine the action or the temporary measures do. 
The third stage is to design improvements based on the analysis method of HIRA and HAZOP worksheet.

\section{Results and Discussion}

\subsection{HIRA and HAZOP Assessment}

The application of HIRA method resulted in the form of hazard identification and risk assessment. Table 1 shows the findings of hazard and risk assessments on the production of batik printing area.

It has found 17 hazards in batik printing workstation. The hazard can be classified into several groups based on the source of danger as in Table 2.

Table 2 Hazard Based on Source

\begin{tabular}{clc}
\hline No & Source of hazard & $\begin{array}{c}\text { Number of poten- } \\
\text { tial hazard }\end{array}$ \\
\hline 1 & Workers attitude & 9 \\
2 & Work posturee & 2 \\
3 & Work procedure & 1 \\
4 & Workstation & 2 \\
5 & Physical work environment & 3
\end{tabular}

17 of potential hazards in the production area of batik printing workstation can be further grouped into five types of hazards include: workers behavior (9), work posture (2), work procedure (1), work station (2), and physical work environment (3).

The findings of the potential hazards of a risk have also been categorized into extreme, high, medium, and low. Based on the results in Figure 2, it can be seen that there are 34\% sources of danger with extreme risk, $24 \%$ source of danger with high risk and medium risk respectively, and the $18 \%$ source of danger with low risk.

Risks to the extreme categories on a risk assessment should be given priority for immediate repairs. The present study indicated that the batik printing is at an extreme high risks based on HIRA analysis.

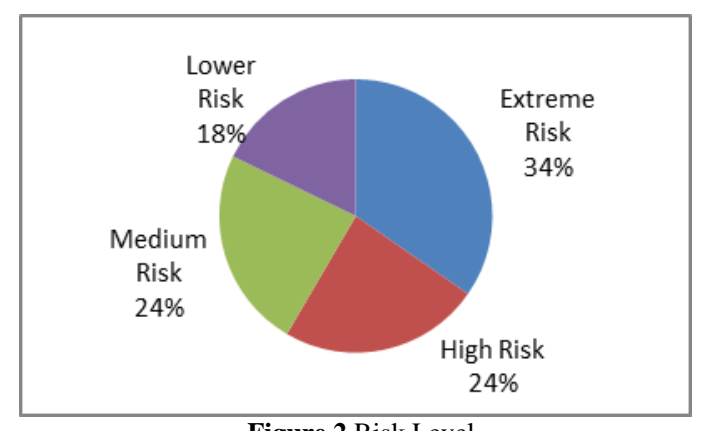

Figure 2 Risk Level

The authors have used HAZOP worksheet to simplify the analysis and discussion of these data. HAZOP worksheet is used to describe the present study in a more detail about the deviations that may occur as well as analyzing the causes of such deviations. Later, the recommendations or proposals are discussed in the HAZOP worksheet based on hazards that have identified in HIRA worksheet.

Use of HIRA and HAZOP method is suitable to be applied to SME batik printing and other textile or garment industries.

\subsection{Improvement in Workplace}

\subsubsection{Worker Attitudes}

Workers often acts unsafe can endanger their safety as workers do not wear a proper PPE (safety gloves, masks, safety shoes, goggles, and apron) to perform the job. The chemical used in the printing process is naphthol, while mixing the dyes use fire soda
$(\mathrm{NaOH})$ and sodium silicate $(\mathrm{Na} 2 \mathrm{SiO} 3)$. The impact of exposure to naphthol can cause in the short term skin irritation, eye irritation, and respiratory tract irritation. Long-term exposure can lead to skin absorption causing damage to the liver, kidneys, anemia, and blood cell disorders [22]. The impact of exposure to chemicals such as fire soda $(\mathrm{NaOH})$, sodium silicate $(\mathrm{Na} 2 \mathrm{SiO} 3)$ on the skin causing redness, pain, blisters, and burns [22]. Workers are working in steaming process is vulnerable in exposing to hot steam and causing eye discomfort and skin blisters [16].

PPE is a tool that has the ability to protect a person whose function is to isolate part or the whole body of the potential hazards in the workplace. Workers in the steaming workstation are required to wear heat resistant gloves, goggles and apron. Furthermore, poster or pocket cards that illustrate examples of workplace accidents due to exposure to chemicals used in the batik industry should be displayed at notice board. With the visual display, the workers will wear PPE to ensure safety in workplace.

\subsubsection{Work Posture}

Workers in printing area starts working at 08.00 a.m until 6.00p.m are exposed to WIB with interlude between 11.30-12.30 WIB. During the printing process, workers are working with the posture up and running continuously. This condition will lead to pain in the nape of the neck, shoulders, upper arms, hips, muscle fatigue, impaired blood circulation in the lower leg. Standing continuously for long periods of time causes lower back pain [3]. In addition, working posture while standing in a long time causing inconvenience to the rest of the body, which are the disorders of blood circulation in the lower leg and muscle fatigue [28]. Continuously standing for more than 4 hours a day, this work posture potentially might causing lower back pain [17]. Work improvement is done by improving the SOP, especially on the determination of the length of time to rest.

\subsubsection{Physical Work Environment}

The measurement results in the working climates at the steaming station obtained the following results: ISBB $31,4^{0} \mathrm{C}$, humidity $70 \%$ and wind velocity $0,035 \mathrm{~m} / \mathrm{s}$. Moreover, it was coupled with the exposure of the appliance steaming hot steam. The measurement results showed that the ISBB value exceed the threshold value (NAV). Based on Minister of Manpower and Transmigration Republic Indonesia Number PER.13/MEN/X2011, the value of the permitted threshold ISBB is $31^{\circ} \mathrm{C}$. Hot environment can cause dizziness, fatigue, muscle pain, cramps, fainting, and the worst result in heat stress [16]. The manufacturing industry workers who died from heat stress are 20 people within the period of 2010-2013 [32]. Improvements can be done by adding ventilation (windows) and installing exhaust fans. The management of the SME is suggested to encourage workers to wear a thin shirt and of material that easily absorbs sweat and frequent drinking water.

In general, the management of the SME should take an appropriate action by making a comprehensive SOP. A good designed of SOP allow workers able to work in accordance with the existing guidelines. Thereby, the potential accidents in workplaces can be minimized.

The advantages of using the method HIRA and HAZOP for present study of SME batik printing:

1. Easy to apply.

2. Do not require great expense.

3. Capable of identifying all potential hazards in the work area in detail.

4. The proposal gives priority improvement based on the risk rating.

5. Able to describe in detail deviations that may occur as well as analyzing the causes of such deviations which 
will then be known what action is good and suited to address the deviations that can lead to accidents.

The proposed improvements were made based on the hazard occurs.

\section{Conclusion}

The objective of this study is to investigate the potential hazards and accidents that might occur at batik printing work station and provide the improvement solutions for prevention of occupational accidents in workplace. This research had integrated the HIRA and HAZOP to achieve the objective of this study. Use of HIRA and HAZOP method is suitable to be applied in SME batik printing and other industries batik (batik cap and batik tulis). In addition, this approach can also be applied to other textile industries (textile and garment). This study will provide a reference for future studies related to the use of methods HIRA and HAZOP especially for batik industry and other manufacturing industries in Indonesia. Moreover, it can help the management and employees to focus on improving safety and health performance in workplace in order to minimize occupational injuries and accidents.

\section{Acknowledgement}

The authors fully acknowledged Universitas Sebelas Maret, PT. Batik Merak Manis and Social Security Organization (SOCSO) for financial supports and ease in data collection which makes this important research viable and effective

\section{References}

[1] Agustina F and Maulana A, "Analisis Postur Kerja dengan Tinjauan Ergonomi di Industri Batik Madura” (Work Posture Analysis with Ergonomic Review in Batik Madura Industry), Jurnal Inovasi dan Kewirausahaan: Kajian di Negara-negara Berkembang, Vol. 1, No. 3, (2012), pp. 167-171, available online: jurnal.uii.ac.id/ajie/article/download/2835/2589

[2] Agusti N, "Perancangan Ulang Ruang dan Peralatan Kerja dengan Pendekatan Ergonomi Bagi Pembatik Tulis pada Pengrajin Batik Tulis X" (Space Design and Work Equipment with Ergonomic Approach for Batik Write on Batik Craftsman Write X), Tesis, Faculty of Public Health, Universitas Indonesia, Depok, (2012).

[3] Anis M, Wijaya GG, Muslimah E, "Implementasi Kesehatan dan Keselamatan Kerja (K3) di Industri Batik: Studi Kasus di Industri Batik GT Laweyan Surakarta" (Implementation of Health and Safety (K3) in Batik Industry: Case Study in Batik Industry GT Laweyan Surakarta), Proceeding of the IENACO, (2015), pp. 139-147, https://publikasiilmiah.ums.ac.id/handle/11617/5757.

[4] Anonim, UNSW Health and Safety, "Risk Management Program Canberra University of New South Wales", (2008), http://www.ohs.unsw.edu.au/ohs-riskmanagement.

[5] Ansori N, Novianti T, Agustina F, Rakhmawati N, "Safety Performance Index pada Industri Batik Tulis Berdasarkan Kriteria Majemuk",(Safety Performance Index on Batik Tulis Industry Based on Multiple Criteria), Jurnal Teknik Industri, Vol 17, No. 2, (2015), pp. 105-110, https://doi.org/10.9744/jti.17.2.105-110

[6] Ayu VEA, "Analisis Potensi Bahaya dengan Metode Hazard Identification and Risk Assessment (HIRA) dan Hazard and Operability Study (HAZOP) (Studi Kasus: Batik Merak Manis Laweyan)", (Potential Hazard Analysis with Hazard Identification and Risk Assessment (HIRA) and Hazard and Operability Study (HAZOP) (Case Study: Batik Merak Manis Laweyan) ", Final Project, Industrial Engineering, Universitas Sebelas Maret, Surakarta, (2016).

[7] BSN, "Definisi dan Penggolongan Pola Batik (SNI 08-0247-1989)", (Definition and Classification of Batik Patterns (SNI 08-02471989), Badan Standarisasi Nasional, Jakarta, (1989).

[8] British Standards Institution, "BS8800: Occupational Health and Safety Management Systems-Guide”, British Standards Institution, London, (2004)

[9] Chastain JW, Delanoy P, Devlin C, Mueller T and Study K, "Beyond HAZOP and LOPA: Four different company approaches", Journal Process Safety Progress, Vol 36, No.1, (2016), pp. 38-53, https://www.researchgate.net/publication/305356686_Beyond_HA ZOP_and_LOPA_Four_different_company_approaches.
[10] Clean Batik Initiative Centre, "Pedoman Penanganan Zat-zat Kimia, Tindakan Pencegahan dan Pertolongan Pertama", (Guidelines for Handling Chemical Substances, First Precautions and First Aid), German-Indonesia Chamber of Industry and Commerce, (2011), http://cleanbatik.com/index.php?id=211

[11] Clean Batik Initiative Centre, "Ho-2 Proses Pembuatan Batik", (Ho-2 Batik Making Process), German-Indonesia Chamber of Industry and Commerce, (2011) http://cleanbatik.com/index.php?id=207

[12] Clean Batik Initiative Centre, "Bahan Kimia Berbahaya dalam Pembuatan Batik", (Dangerous Chemicals in the Making of Batik), German-Indonesia Chamber of Industry and Commerce, (2011), http://cleanbatik.com/index.php?id=207

[13] D. Lafond, A. Champagne, M. Descarreaux, J.D. Dubois, J.M. Prado, and M. Duarte, "Postural Control During Prolonged Standing in Persons with Chronic Low Back Pain”, Journal Gait \& Posture,

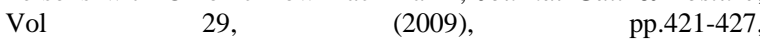
https://doi.org/10.1016/j.gaitpost.2008.10.064

[14] Dunjo J, Fthenakis V, Vilchez, JA, Arnaldos J, "Hazard and operability (HAZOP) analysis, A literature review", Journal Hazardous Materials, Vol. 173, No. 1, (2009), pp 19-32.

[15] Gokul, Raj S., Shivasankaran N, "Hazard Identification and Risk Assessment in Deinking Plant", International Journal of Research In Aeronautical and Mechanical Engineering, Vol 2 Issue 3, (2014), pp 202-208

[16] Haditia IP, “Analisis Pengaruh Suhu Tinggi Lingkungan dan Beban Kerja Terhadap Konsentrasi Pekerja", (Analysis of the Effect of High Temperature Environment and Workload on Worker Concentration), Final Project, Industrial Engineering, Universitas Indonesia, Depok, (2012)

[17] J.K. William, S.V.Jeff, A.B.Jill, A.G. Lincoln, R. W. Paul, L. G. Ana, M. Z. Vladimir, D. Marcos, and A. R. Nicholas, "Influence of Compression Hosiery on Physiological Responses to Standing Fatique in Women", Journal Medicine \& Science in Sports \& Exercise, (2000), pp. $1849-1858$

[18] Jusoh, Z., Shattar Abd, N., Majid Abd, H. A, M., Adenan, N, D, "Determination of Hazard in Captive Hotel Laundry Using Semi Quantitative Risk Assessment Matrix", Procedia - Social and Behavioral Sciences, 222, (2016), pp 915-922

[19] Kotek, L., Tabas, M., "HAZOP study with qualitative risk analysis for prioritization of corrective and preventive actions", Procedia Engineering, Vol. 42, No. 4, (2012), pp $808-815$

[20] Kumar, M. Saravana., Kumar, Dr. P. Senthil., "Hazard Identification and Risk Assessment in Foundry", IOSR Journal of Mechanical and Civil Engineering (IOSR-JMCE), (2014), pp. 33-37

[21] Legget, David J, "Lab-HIRA: Hazard Identification and Risk Analysis for the Chemical Research Laboratory Part 2. Risk Analysis of Laboratory Operations", Journal of Chemical Health \& Safety, September-October, (2012), pp 25-36

[22] Lestari F, "Bahaya Kimia: Sampling dalam Pengukuran Kontaminan Kimia di Udara", (Chemical Hazards: Sampling in Measurement of Chemical Contaminants in Air), Penerbit Buku Kedokteran EGC, (2007)

[23] Lind, S., Nenonen, S. and Rahnasto, J.K., "Safety Risk Assessment in Industrial Maintenance", Journal of Quality in Maintenance Engineering, Vol. 14, No. 2, (2008), pp. 205-217

[24] Makin, A.M and Winder, C., "Managing Hazards in the Workplace using Organizational Safety Management Systems: A Safe Place, Safe Person, Safe Systems Approach", Journal of Risk Research, Vol. 12, Issue 3-4, (2009), pp. 329-343

[25] Mokaliran, C., Panjaitan, Togar W.S., "Peningkatan Perilaku Aman di PT. XXX dengan Pendekatan Behavior Based Safety", (Enhancement of Safe Behavior at PT. XXX with Behavior Based Safety Approach), Jurnal Titra, Vol. 3, No. 2 (2015), pp 79-83

[26] NIOSH, "Training Manual for Safety \& Health Officer Certificate Programme", Malaysia, (2005)

[27] Noriyati, R.D., Rozaaq, W., Musyafa, A., Soepriyanto, A., "Hazard $\&$ operability study and determining safety integrity level on sulfur furnace unit, A case study infertilizer industry", Procedia Manufacturing, Vol 4, (2015), pp $231-236$

[28] P. Madeleine, M. Voight, and L. Arendt-Nielsen., "Subjective, Physiological and Biomechanical Responses to Prolonged Manual Work Performed Standing on Hard and Soft Surface", European Journal of Applied Physiology and Occupational Physiology, Vol 77, issue (1-2), (1998), pp 1-9

[29] SK Menperin, Surat Keputusan Menteri Perindustrian Indonesia No.19/M/I/1986 Industry Classification, Ministry of Industry Republic of Indonesia, (1998) 
[30] SNI 08-0247, "Definisi dan penggolongan pola batik", (Definition and classification of batik pattern). Badan Standarisasi Nasional, (1998)

[31] Syamwil R, Kusumastuti A, Nurrohmah S, "Peningkatan Kinerja Industri Batik Melalui Penerapan Standar Operational Procedure, Lingkungan, Serta Kesehatan dan Keselamatan Kerja, Rekayasa”, (Improving Batik Industry Performance Through Implementation of Standard Operational Procedure, Environment, And Health and Safety, Engineering), Jurnal Penerapan Teknologi dan Pembelajaran, Vol. 8, No. 1, (2010), pp. 30-36

[32] Tamura, Naoya., Tanaka, Takehiro., “Japan's Recent Tendencies of Accidents in Building Facilities and Workers Accidents in The Environment of Extreme Temperature", Procedia Engineering, Vol. 146,(2016), pp 278-287

[33] Tarwaka, "Keselamatan dan Kesehatan Kerja "Manajemen dan Implementasi K3 di Tempat Kerja" 2nd ed, (Occupational Safety and Health "Management and Occupational Safety and Health Implementation at Work), Harapan Pres, (2014).

Table 1 Finding Hazard and Risk Assessment

\begin{tabular}{|c|c|c|c|c|c|c|c|c|c|}
\hline No & Location & Picture & $\begin{array}{c}\text { Hazard Explana- } \\
\text { tion }\end{array}$ & Risk & $\begin{array}{c}\text { Source of Haz- } \\
\text { ard } \\
\end{array}$ & $\mathbf{L}$ & $\mathbf{C}$ & $\mathbf{S}$ & $\begin{array}{c}\text { Risk } \\
\text { Level } \\
\end{array}$ \\
\hline 1 & Printing & & $\begin{array}{l}\text { The floor is slip- } \\
\text { pery and dirty } \\
\text { because the dye } \\
\text { splatter }\end{array}$ & Workers slip down & Slippery floor & 3 & 1 & 3 & Low \\
\hline 2 & $\begin{array}{l}\text { Printing Prep- } \\
\text { aration }\end{array}$ & & $\begin{array}{l}\text { Workers working } \\
\text { with unnatural } \\
\text { posture (bent) }\end{array}$ & $\begin{array}{l}\text { Cause pain in the nape of } \\
\text { the neck, shoulders, and } \\
\text { waist }\end{array}$ & $\begin{array}{l}\text { Printing table is } \\
\text { too low }\end{array}$ & 2 & 2 & 4 & Low \\
\hline 3 & Printing & & $\begin{array}{l}\text { Workers effected } \\
\text { by naptol on hand }\end{array}$ & $\begin{array}{l}\text { Short term exposure: } \\
\text {-contact to skin affected } \\
\text { irritation } \\
\text { Long term exposure: } \\
\text {-contact to skin (absorbed } \\
\text { through the skin) will } \\
\text { damage the heart, kid- } \\
\text { neys, anemia, and blood } \\
\text { cell disorders }\end{array}$ & Naptol & 3 & 3 & 9 & High \\
\hline 4 & Printing & & $\begin{array}{l}\text { Workers effected } \\
\text { by naptol in the } \\
\text { eyes }\end{array}$ & $\begin{array}{l}\text { Contact to eyes cause } \\
\text { some irritation }\end{array}$ & Naptol & 2 & 3 & 6 & Medium \\
\hline 5 & Printing & & $\begin{array}{l}\text { Workers breath in } \\
\text { the naptol }\end{array}$ & $\begin{array}{l}\text { Contact with the respira- } \\
\text { tory will causes tract } \\
\text { irritation including cough- } \\
\text { ing and sneezing }\end{array}$ & Naptol & 3 & 3 & 9 & High \\
\hline 6 & Printing & & $\begin{array}{l}\text { Workers effected } \\
\text { by naptol on the } \\
\text { foot }\end{array}$ & $\begin{array}{l}\text { Short term exposure: } \\
\text {-contact to skin affected } \\
\text { irritation } \\
\text { Long term exposure: } \\
\text {-contact to skin (absorbed } \\
\text { through the skin) will } \\
\text { damage the heart, kid- } \\
\text { neys, anemia, and blood } \\
\text { cell disorders }\end{array}$ & Naptol & 2 & 3 & 6 & Medium \\
\hline 7 & Printing & & $\begin{array}{l}\text { Workers work in a } \\
\text { standing position } \\
\text { and runs continu- } \\
\text { ously during the } \\
\text { working hours }\end{array}$ & $\begin{array}{l}\text { Cause pain in the nape of } \\
\text { the neck, shoulders, upper } \\
\text { arms, hips, muscle fa- } \\
\text { tigue, impaired blood } \\
\text { circulation in the lower } \\
\text { leg }\end{array}$ & $\begin{array}{l}\text { Printing works } \\
\text { procedure }\end{array}$ & 4 & 3 & 12 & Extreme \\
\hline
\end{tabular}




\begin{tabular}{|c|c|c|c|c|c|c|c|c|}
\hline 8 & Drying & $\begin{array}{l}\text { Workers effected } \\
\text { by naptol on hand }\end{array}$ & $\begin{array}{l}\text { Short term exposure: } \\
\text {-contact to skin affected } \\
\text { irritation }\end{array}$ & Naptol & 2 & 3 & 6 & Medium \\
\hline 9 & Drying & $\begin{array}{l}\text { Workers stands on } \\
\text { the table }\end{array}$ & Falls from top of the table & $\begin{array}{l}\text { The drying pro- } \\
\text { cess is on the } \\
\text { table }\end{array}$ & 2 & 2 & 4 & Low \\
\hline 10 & $\begin{array}{l}\text { Mixing the } \\
\text { dyes }\end{array}$ & $\begin{array}{l}\text { Workers exposed } \\
\text { to chemical fire } \\
\text { soda }(\mathrm{NaOH}) \text {, } \\
\text { sodium silicate } \\
\left(\mathrm{Na}_{2} \mathrm{SiO}_{3}\right) \text { on their } \\
\text { foot }\end{array}$ & $\begin{array}{l}\text { Contact with skin causes } \\
\text { redness, pain, blisters, and } \\
\text { serious skin burns }\end{array}$ & $\begin{array}{l}\text { Chemical fire } \\
\text { soda }(\mathrm{NaOH}) \text {, } \\
\text { sodium silicate } \\
\left(\mathrm{Na}_{2} \mathrm{SiO}_{3}\right)\end{array}$ & 4 & 3 & 12 & Extreme \\
\hline 11 & $\begin{array}{l}\text { Mixing the } \\
\text { dyes }\end{array}$ & $\begin{array}{l}\text { Workers exposed } \\
\text { to chemical fire } \\
\text { soda }(\mathrm{NaOH}) \text {, } \\
\text { sodium silicate } \\
\left(\mathrm{Na}_{2} \mathrm{SiO}_{3}\right) \text { on their } \\
\text { hand }\end{array}$ & $\begin{array}{l}\text { Contact with skin causes } \\
\text { redness, pain, blisters, and } \\
\text { serious skin burns }\end{array}$ & $\begin{array}{l}\text { Chemical fire } \\
\text { soda }(\mathrm{NaOH}) \text {, } \\
\text { sodium silicate } \\
\left(\mathrm{Na}_{2} \mathrm{SiO}_{3}\right)\end{array}$ & 4 & 3 & 12 & Extreme \\
\hline 12 & $\begin{array}{l}\text { Mixing the } \\
\text { dyes }\end{array}$ & $\begin{array}{l}\text { Workers exposed } \\
\text { to chemical fire } \\
\text { soda }(\mathrm{NaOH}) \text {, } \\
\text { sodium silicate } \\
\left(\mathrm{Na}_{2} \mathrm{SiO}_{3}\right) \text { on their } \\
\text { eyes }\end{array}$ & $\begin{array}{l}\text { Contact with skin causes } \\
\text { redness, pain, blisters, and } \\
\text { serious skin burns }\end{array}$ & $\begin{array}{l}\text { Chemical fire } \\
\text { soda }(\mathrm{NaOH}) \text {, } \\
\text { sodium silicate } \\
\left(\mathrm{Na}_{2} \mathrm{SiO}_{3}\right)\end{array}$ & 4 & 3 & 12 & Extreme \\
\hline 13 & $\begin{array}{l}\text { Mixing the } \\
\text { dyes }\end{array}$ & $\begin{array}{l}\text { Workers breathe } \\
\text { in the chemicals } \\
\text { soda fire }(\mathrm{NaOH}) \\
\text { and sodium sili- } \\
\text { cate }\left(\mathrm{Na}_{2} \mathrm{SiO}_{3}\right)\end{array}$ & $\begin{array}{l}\text { Contact with the respira- } \\
\text { tory tract causing sore } \\
\text { throat, coughing, short- } \\
\text { ness of breath, and throat } \\
\text { burning }\end{array}$ & $\begin{array}{l}\text { Chemical fire } \\
\text { soda }(\mathrm{NaOH}) \text {, } \\
\text { sodium silicate } \\
\left(\mathrm{Na}_{2} \mathrm{SiO}_{3}\right)\end{array}$ & 4 & 3 & 12 & Extreme \\
\hline 14 & Steaming & $\begin{array}{l}\text { Workers exposed } \\
\text { to hot steam } \\
100^{\circ} \mathrm{C}\end{array}$ & $\begin{array}{l}\text { The skin becomes red, } \\
\text { and also cause the skin } \\
\text { blister }\end{array}$ & $\begin{array}{l}\text { Hot steam from } \\
\text { the steaming } \\
\text { chamber }\end{array}$ & 3 & 3 & 9 & High \\
\hline 15 & Steaming & $\begin{array}{l}\text { Workers exposed } \\
\text { to hot steam } \\
100^{\circ} \mathrm{C}\end{array}$ & Sore eyes & $\begin{array}{l}\text { Hot steam from } \\
\text { the steaming } \\
\text { chamber }\end{array}$ & 3 & 3 & 9 & High \\
\hline 16 & Steaming & $\begin{array}{l}\text { Workers exposed } \\
\text { to heat room } \\
\text { temperature }\end{array}$ & $\begin{array}{l}\text { Causing heat stress symp- } \\
\text { toms, such as dizziness, } \\
\text { fatigue, muscle pain, } \\
\text { cramps, impaired con- } \\
\text { sciousness }\end{array}$ & $\begin{array}{l}\text { Temperature } \\
34,3^{0} \mathrm{C} \text {, humidity } \\
70 \% \text {, wind veloci- } \\
\text { ty } 0,035 \mathrm{~m} / \mathrm{s} \text {, and } \\
\text { ISBB } 31,4^{0} \mathrm{C}\end{array}$ & 4 & 3 & 12 & Extreme \\
\hline 17 & Steaming & $\begin{array}{l}\text { Workers working } \\
\text { with unnatural } \\
\text { posture (bent) }\end{array}$ & $\begin{array}{l}\text { Cause the pain in the nape } \\
\text { of the neck, shoulders, } \\
\text { hips, and thighs. }\end{array}$ & $\begin{array}{l}\text { Steaming tool } \\
\text { design doesn't } \\
\text { comply with } \\
\text { workers anthro- } \\
\text { pometry }\end{array}$ & 3 & 2 & 6 & Medium \\
\hline
\end{tabular}

Table 3 HAZOP Worksheet

\begin{tabular}{|c|c|c|c|c|c|}
\hline No & $\begin{array}{l}\text { Source of Haz- } \\
\text { ard }\end{array}$ & Deviation & Cause & Consequences & Action \\
\hline 1 & Workers attitude & $\begin{array}{l}\text { Workers acted unsafe } \\
\text { Workers don't use any } \\
\text { Personal Protective } \\
\text { Equipment (PPE): } \\
\text { 1. Safety gloves } \\
\text { 2. Masker } \\
\text { 3. Safety shoes } \\
\text { 4. Safety goggles } \\
\text { 5. Apron } \\
\text { 6. The heat resistant } \\
\text { gloves }\end{array}$ & $\begin{array}{l}\text { 1. Undisciplined behavior } \\
\text { of workers. } \\
\text { 2. The low awareness of } \\
\text { work safety } \\
\text { knowledge. } \\
\text { 3. The low awareness of } \\
\text { the entrepreneurs about } \\
\text { health issues and safe- } \\
\text { ty. } \\
\text { 4. Provision of PPE was } \\
\text { minimal. }\end{array}$ & $\begin{array}{l}\text { Affected by chemical, naptol: } \\
\text { Short-term exposure: } \\
\text { Skin irritation, eye irritation, respir- } \\
\text { atory tract irritation. } \\
\text { Long-term exposure: } \\
\text { Absorbed through skin causing } \\
\text { damage to the liver, kidneys, ane- } \\
\text { mia, and blood cell abnormalities. } \\
\text { Exposed to chemical fire soda } \\
\left(\mathrm{NaOH}^{2}, \text { Sodium silicate }\right. \\
\left(\mathrm{Na}_{2} \mathrm{SiO}\right) \text { : } \\
\text { 1. Contact with skin causes red- } \\
\text { ness, pain, blisters, and burns. } \\
\text { 2. Contact with the eyes causes }\end{array}$ & $\begin{array}{l}\text { 1. Make a visual dis- } \\
\text { play to remind the } \\
\text { workers to always } \\
\text { use PPE. } \\
\text { 2. Make a good work } \\
\text { procedure. } \\
\text { 3. K3 training for } \\
\text { workers. } \\
\text { 4. Provide sufficient of } \\
\text { PPE. }\end{array}$ \\
\hline
\end{tabular}




\begin{tabular}{|c|c|c|c|c|c|}
\hline & & & & $\begin{array}{l}\text {.redness, pain, blurred vision, } \\
\text { sores in the eye. } \\
\text { 3. Contact with the respiratory tract } \\
\text { causing sore throat, cough, } \\
\text { shortness of breath, throat burn- } \\
\text { ing. } \\
\text { Exposure to hot steam: } \\
\text { eye irritation, skin becomes red, } \\
\text { might cause the skin to blister. }\end{array}$ & \\
\hline 2 & Work posture & $\begin{array}{l}\text { Workers work in a stand- } \\
\text { ing position and runs con- } \\
\text { tinuously during business } \\
\text { hours ( } 7 \text { hours / day) }\end{array}$ & $\begin{array}{l}\text { The production process in } \\
\text { printing that requires } \\
\text { workers to work while } \\
\text { standing. }\end{array}$ & $\begin{array}{l}\text { Causing pain in the nape of the } \\
\text { neck, shoulders, upper arms, hips, } \\
\text { muscle fatigue, impaired blood } \\
\text { circulation in the lower leg. }\end{array}$ & $\begin{array}{l}\text { Making a good proce- } \\
\text { dural of works. }\end{array}$ \\
\hline 3 & $\begin{array}{l}\text { Physical work } \\
\text { environments }\end{array}$ & $\begin{array}{l}\text { ISBB in printing room } \\
31,4^{0} \mathrm{C} \\
\text { Humidity } 70 \% \\
\text { Wind velocity } 0,035 \mathrm{~m} / \mathrm{s}\end{array}$ & $\begin{array}{l}\text { Ventilation in the batik } \\
\text { printing station is less } \\
\text { good. }\end{array}$ & $\begin{array}{l}\text { Workers exposed to heat which can } \\
\text { lead to: dizziness, fatigue, muscle } \\
\text { pain, cramps, fainting, and the most } \\
\text { severe experienced heat stress }\end{array}$ & $\begin{array}{l}\text { Employers try to fix the } \\
\text { ventilation at the work } \\
\text { station of batik printing } \\
\text { by installing exhaust } \\
\text { fan. }\end{array}$ \\
\hline
\end{tabular}

